\title{
大洗港による那珂川流出土砂のトラップと遮蔽域内堆砂の実態
}

\section{Trapping of Sediment Supplied from Naka River by Oharai Port Breakwater and Sedimentation inside its Wave-shelter Zone}

\author{
谷沢 肇 $^{1} \cdot$ 宇多高明 ${ }^{2} \cdot$ 松浦健郎 $^{3} \cdot$ 菊池泉弥 $^{4} \cdot$ 福本崇嗣 ${ }^{5} \cdot$ 熊田貴之 $^{6}$ \\ Hajime YAZAWA, Takaaki UDA, Takeo MATSU-URA, Izumi KIKUCHI \\ Takashi FUKUMOTO and Takayuki KUMADA
}

\begin{abstract}
Beach changes around Oharai Port facing the Pacific Ocean were investigated using bathymetric survey data collected between 1979 and 2004. Between the south and offshore breakwaters of Oharai Port, $1.50 \times 10^{6} \mathrm{~m}^{3}$ of fine sand deposited between 1979 and 2004, resulting in the annual rate of $6.0 \times 10^{4} \mathrm{~m}^{3} / \mathrm{yr}$, which was originally supplied from the Naka River $3 \mathrm{~km}$ north of the port. Also in the wave-shelter of the offshore breakwater on the south side, $7.0 \times 10^{6}$ $\mathrm{m}^{3}$ of fine sand deposited between 1979 and 2004, giving the annual rate of $2.8 \times 10^{5} \mathrm{~m}^{3} / \mathrm{yr}$ which was transported by the northward longshore sand transport induced from outside to inside the wave-shelter zone of the offshore breakwater.
\end{abstract}

\section{1. まえがき}

鹿島灘海岸は，太平洋に面し大洗から波崎まで延びる 長さ $97 \mathrm{~km}$ の海岸線である.この海岸の主な漂砂源は, 大洗港の北約 $3 \mathrm{~km}$ に流入する那珂川と, 海岸線南端の波 崎より流入する利根川からの供給土砂であり, これらの 河川からの供給土砂が沿岸に堆積して海浜が形成されて きた。しかし, 現在では鹿島灘中央部には鹿島港が立地 し, その先端水深が $24 \mathrm{~m}$ と, 当海岸の波による地形変化 の限界水深 (約 $9 \mathrm{~m}$ ) より十分深い南防波堤が存在するこ とから, 利根川からの流出土砂は鹿島港以北に移動する ことができない. 一方, 鹿島灘海岸の北端には大洗港が あり，そこでは南防波堤と沖防波堤の建設とともに波の 遮蔽域が形成され, 大洗港の南側海岸では北向きの沿岸 漂砂が誘起されている。この海岸の海浜変形に関しては, 三村ら（1991）が1979〜 1990年の深浅データを用いて 平面的地形変化を分析し, 大洗港の南側海岸と沖防波堤 背後で著しい堆積が生じたこと, および大洗港の南側海 岸の地形変化は, 南防波堤と沖防波堤の背後に形成され た波の遮蔽域へと向かう北向きの沿岸漂砂に起因すると した。また宇多（1997）は，1981～1984年の3力年で大 洗港の南 $2 \mathrm{~km}$ 地点を通過して大洗港へと移動した沿岸漂 砂量を $2.3 \times 10^{5} \mathrm{~m}^{3} / \mathrm{yr}$ と推定し, また 1978 1984年での 総堆積土砂量は $1.1 \times 10^{6} \mathrm{~m}^{3}$ に達したことを明らかにし

\begin{tabular}{|c|c|c|}
\hline 1 & & 茨城県水戸土木事務所河川整備課 課長 \\
\hline 2 正会員 & 工博 & $\begin{array}{l}\text { (䝧) 土木研究センター常務理事なぎさ } \\
\text { 総合研究室長兼日本大学客員教授理工学 } \\
\text { 部海洋建築工学科 }\end{array}$ \\
\hline 3 & & 茨城県高萩工事事務所河川整備課 主任 \\
\hline 4 & & 茨城県常陸大宮土木事務所河川整備課 \\
\hline 5 & & 東京都庁港湾課 ～～～～～～～ \\
\hline 6 正会員 & 工博 & (株) 水圈科学コンサルタント \\
\hline
\end{tabular}

た.さらにその後の地形変化に関しては，木村ら（2006） が大洗港の南側海岸における1984～2005年の堆積土砂 量の経年変化を調べ，この間約 $5.0 \times 10^{6} \mathrm{~m}^{3}$ の土砂が大洗 港の南側海岸に堆積したことを示した。このように大洗 港の南防波堤と沖防波堤の延伸とともに地形変化が進ん できたが, 三村らを除く既往研究では, 堆積土砂量の変 化は把握されているものの, 縦断形や底質粒径まで含め た検討は十分ではなく, また那珂川から鹿島灘海岸への 流入土砂量の定量評価については課題として残されてい た. そこで本研究では, 大洗港の南側海岸の海浜変形の 詳細と遮蔽域へと向かう沿岸漂砂量を調べるとともに, 沖防波堤によってトラップされた那珂川起源の沿岸漂砂 量を調べ, これらに起因して起きている過剩堆砂を防止 する策について考察する.

\section{2. 深浅図による平面的地形変化の分析}

図-1 は2006年撮影の大洗港周辺の空中写真である. 同 種の空中写真は木村ら（2006）でも示したが，木村らの 示した 2002 年の空中写真と比較すると, 南北方向に約 $900 \mathrm{~m}$ の沖防波堤の南端に「く」の字形の長さ約 $300 \mathrm{~m}$ の 斜め防波堤が伸ばされた。この海岸における卓越波向は 木村ら（2006）によればEのため沖防波堤の背後に広い 波の遮蔽域が形成され, 波の遮蔽域内へと南側海岸から 沿岸漂砂が生じ, 波の遮蔽域では砂が堆積して前浜が大 きく広がった．西防砂堤との接点での汀線は1964年当時 と比較して約 $750 \mathrm{~m}$ も前進し, これと対照的に南側海岸 では汀線が後退して護岸が波に直接曝されている。

図-1に示す区域では1979年から毎年 1 回, 沿岸方向に $200 \mathrm{~m}$ 間隔の測線に沿って深浅測量が行われてきている. このデータは三村が分析したものと同一であるが, 分析 期間を2006年までとして詳細分析を行った。以下ではま 


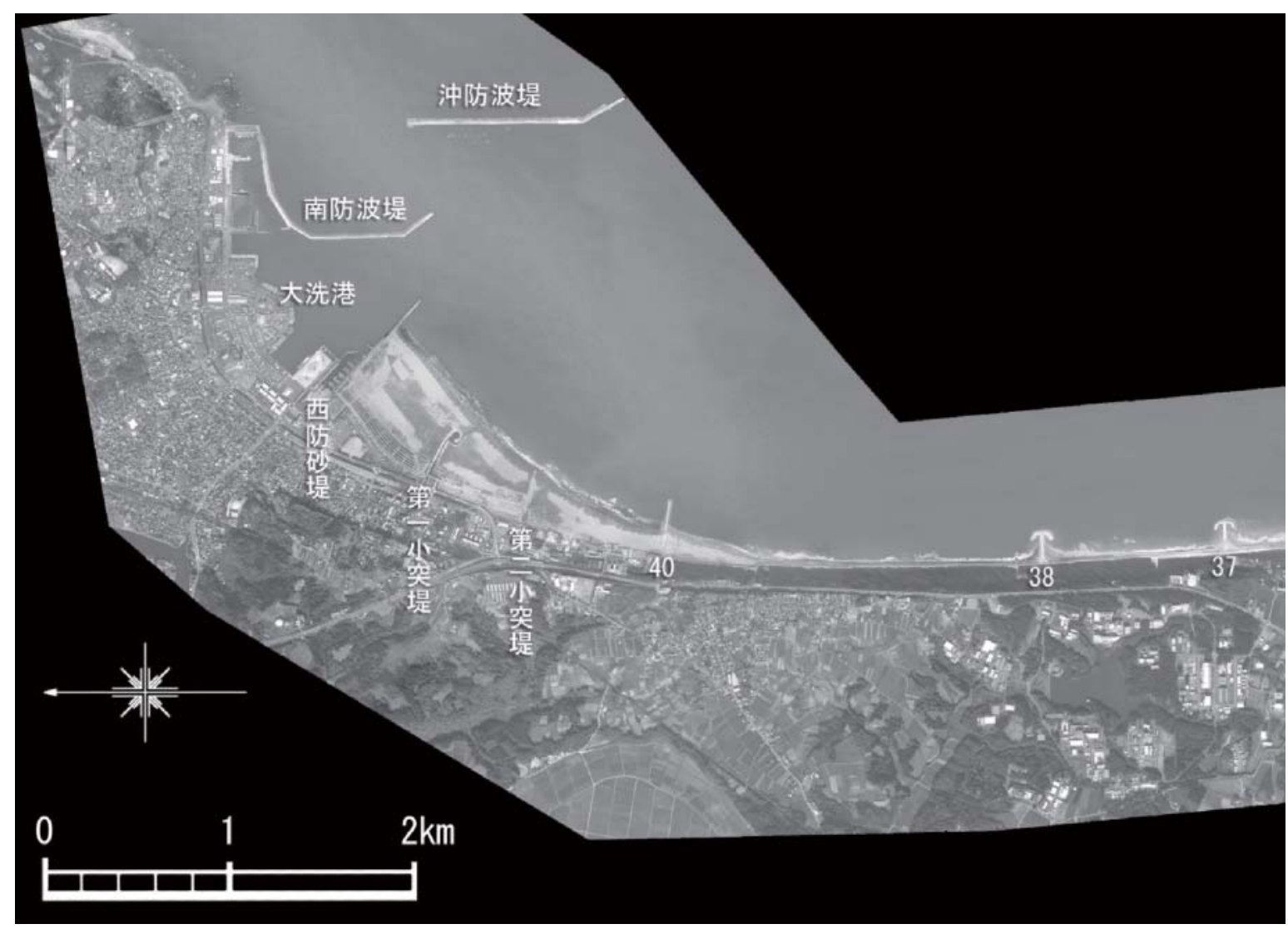

図-1 大洗港周辺の空中写真（2006年）

ず代表時期として 1980，1990，2000，2004年の4時期を 選んで深浅図を示す。なお各図には1979年を基準とした 水深変化量を算出し，その平面分布も併せて示す.

1980年では, 図-2に示すように沖防波堤はなく, 大洗 港の南防波堤のみが延びていた. また現西防砂堤の基部 の $500 \mathrm{~m}$ 部分のみが造られていた。大洗港の南側では-10 $\mathrm{m}$ の等深線に特徵的なように, 大洗港沖から SW方向に 伸びた等深線がほぼ南北方向に向きを変え，その後海岸 線と平行に伸びていた。また大洗港の東沖の広い区域に は岩礁帯が発達している。1990年になると，図-3に示す ように沖防波堤が $800 \mathrm{~m}$ まで伸ばされ，それによる波の 遮蔽効果によって西防砂堤の南側区域では著しい堆砂が 起きた。これと対照的に, 堆積域の南側海岸では侵食が 著しい。注目されるのは，沖防波堤と南防波堤に挟まれ た区域にも堆積域が見られることである。この堆積域は 大洗港の航路を跨いだ北側の，しかも南防波堤の東側域 にあるので，南側から沿岸漂砂によって運ばれた土砂が 堆積したものではなく，北側から南向きの沿岸漂砂によ って運ばれてきた砂が堆積したものと考えられる。

2000 年には，図-4に示すように沖防波堤が先端部も含 めて延伸された結果, 大洗港の南側海岸では堆積が一層
著しくなった。同時に，先端部が南東方向に曲げられた 南防波堤に沿って，沖防波堤方向へと細長い堆積域が伸 びている. その堆積状況から判断して, 砂は南防波堤に 沿って南向きに移動し, 沖防波堤背後の静穏域に堆積し たと推定できる。

2004年では，図-5に示すように，2000年に見られた特 徵が更に顕著になった。とくに南防波堤と沖防波堤の間 の堆積域にあっては，先端が南東方向に銁状に曲げられ た防波堤に沿って沖防波堤方向へと細長い堆積域が大き く伸びた.

\section{3. 堆積土砂量の変遷}

図-2〜図-5に示したように，大洗港周辺にあっては西 防砂堤の南側区域と，南防波堤と沖防波堤に挟まれた区 域で堆積が進んできた。このことから図-5に示すように それぞれの堆積域を囲む区域（区域(1)，(2)）を設定し， これら区域内での1979年以降の堆積土砂量の変化を調べ た.まず西防砂堤以南に設定された区域(1)の堆積土砂量 の経年変化を図-6に示す. 区域(1)の堆積土砂量は時間経 過とともに増大しており，1979年から2004年までに総量 で $7.0 \times 10^{6} \mathrm{~m}^{3}$ の土砂が堆積した。堆積割合は $2.8 \times 10^{5} \mathrm{~m}^{3} / \mathrm{yr}$ 


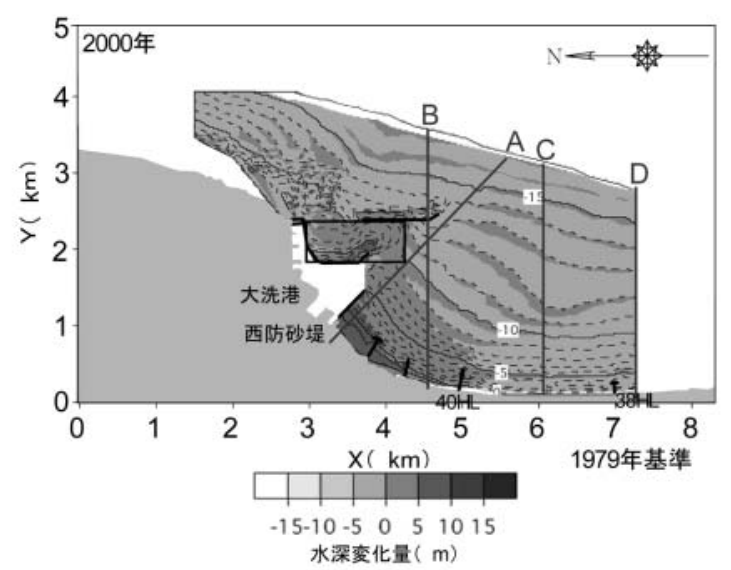

図-2 深浅図（1980年）

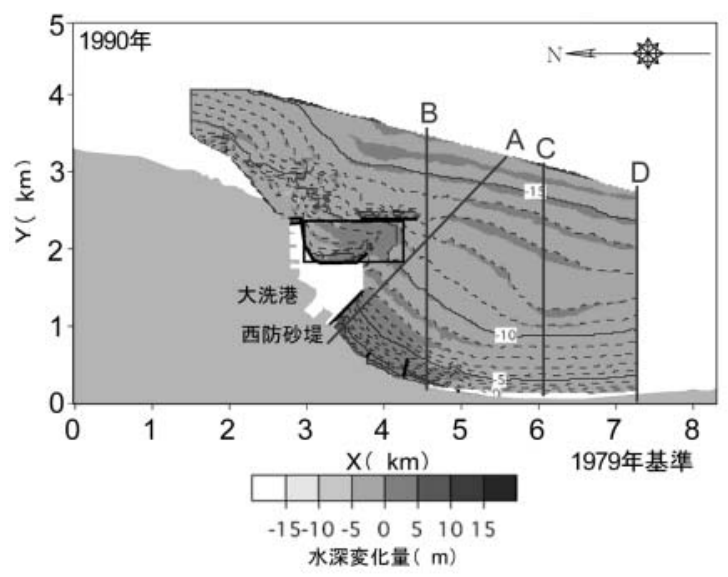

図-3 深浅図（1990年）

である。この值は，木村ら（2006）が示した1984〜2005 年の増加割合 $2.5 \times 10^{5} \mathrm{~m}^{3} / \mathrm{yr}$ とほほ等しい結果となった. 同様にして南防波堤と沖防波堤間の区域(2)での堆積量の 変化も図-6に示す.この区域では1979年から 2004年まで に総量で $1.5 \times 10^{6} \mathrm{~m}^{3}$ の土砂が堆積しており，堆積速度は $6.0 \times 10^{4} \mathrm{~m}^{3} / \mathrm{yr}$ となる. 区域(2)に堆積した土砂は大洗港の 北側区域から運び込まれる以外方法がないこと，また大 洗港の北 $3 \mathrm{~km}$ には那珂川が流入し, 河口部では南向きの 沿岸漂砂が卓越していること（宇多ら，2007）を考慮す れば，この土砂堆積は那珂川からの流出土砂が沿岸漂砂 によって運ばれ，堆積したことによると考えられる。こ れより那珂川の流出土砂量のうち海浜形成に役立つ粒径 成分の土砂流入量は $6.0 \times 10^{4} \mathrm{~m}^{3} / \mathrm{yr}$ となる. 宇多ら (2007) は，鹿島灘海岸の南端に位置する波崎において太平洋に 注ぐ利根川の流下土砂量を, 波崎海岸の海浜土砂量の増 加割合よりほぼ $1.0 \times 10^{5}$ 万 $\mathrm{m}^{3} / \mathrm{yr}$ と推定したが，これと那 珂川からの流出土砂量を比較すると那珂川では利根川に 対して0.6倍であることが分かる.

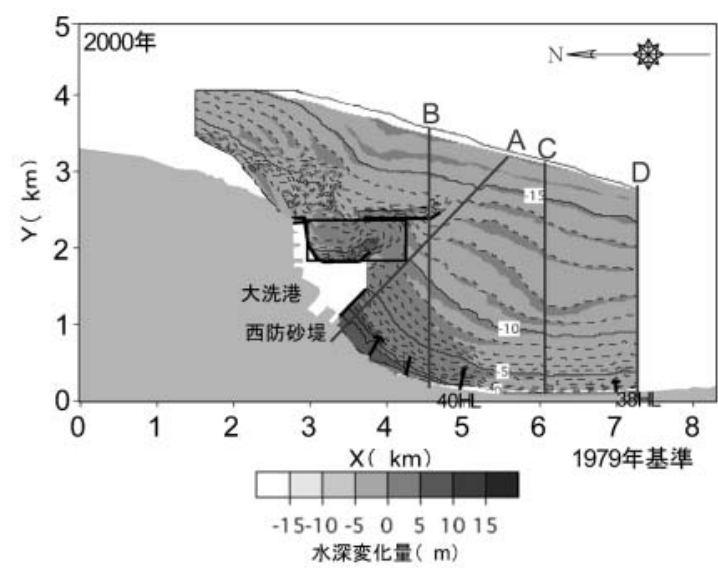

図-4 深浅図 (2000年)

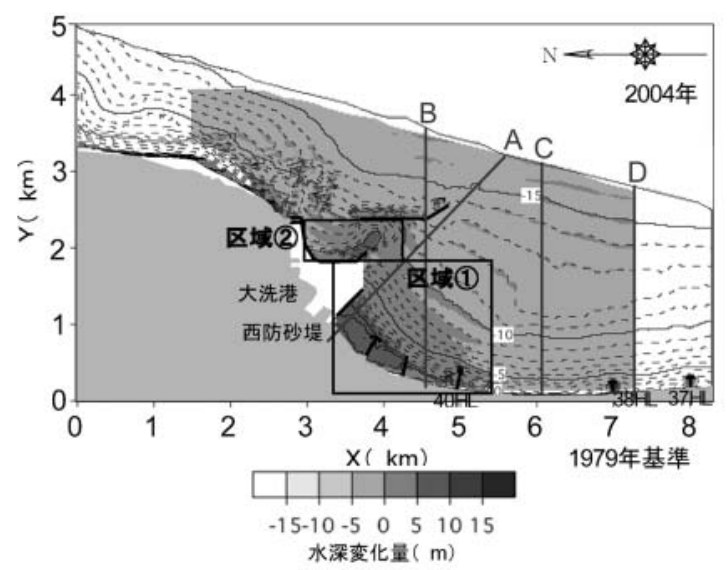

図-5 深浅図（2004年）

\section{4. 海浜縦断形の変化と底質中央粒径}

大洗港の西防砂堤の南側区域の地形変化の詳細を調べ るために，図-2〜4に示したように，堆積域に測線 $\mathrm{A}, \mathrm{B}$ を, 南側の侵食域に測線 C, D を設定して縦断形の変化 を調べた. 測線 A, B, C, Dの縦断形変化を図-7〜図-10 に示す。測線Aでは，1984年から 2004 年に汀線が 400m

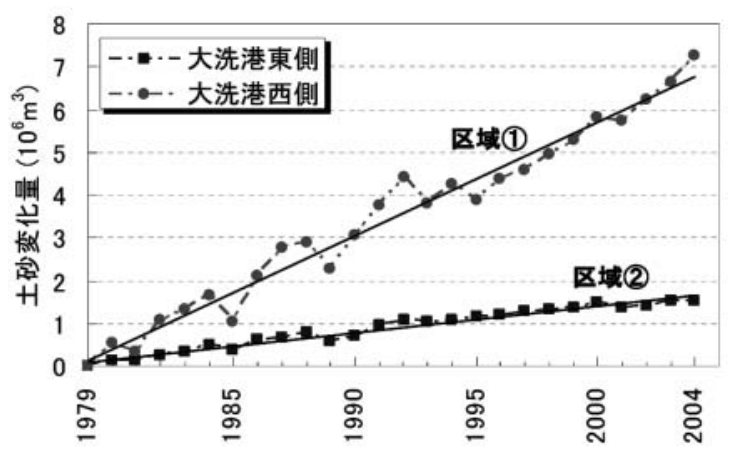

図-6 堆積土砂量の変遷 


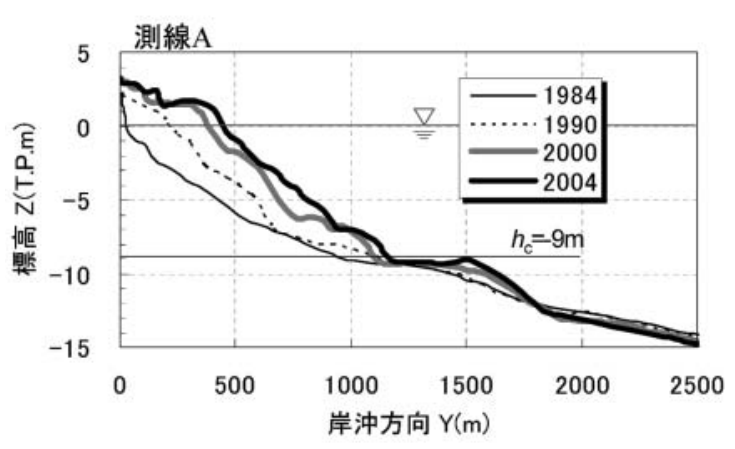

図-7 縦断形変化（測線 $\mathrm{A} ）$

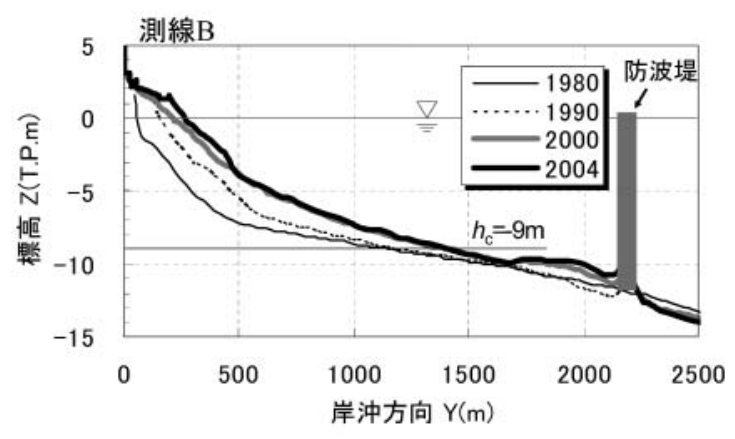

図-8 縦断形変化（測線 B）

前進したが，沖合でも砂の堆積が進み緩やかな勾配の海 底面が形成された。砂の堆積はほぼ水深 $9 \mathrm{~m}$ まで起きて いる. 一部 $\mathrm{Y}=1500 \mathrm{~m}$ 付近にも砂の堆積が見られるが，こ れは測線が沖防波堤の先端付近に位置するため局所洗掘 の影響を拾ったためと考えられる。測線 Bでも A と同様 堆積が進んでおり，鉛直上方に凹状の縦断形がその縦断 勾配が小さくなりつつ前進している１980年頃には急哚 な縦断形であったのはその当時測線Bが侵食域にあった が，防波堤の延長とともに測線 $\mathrm{B}$ の汀線付近が波の遮蔽 域に含まれ，堆積傾向に変わったためである，測線 Bで も波による地形変化の限界水深はほぼ $9 \mathrm{~m}$ にある.

侵食域にある測線 C，Dでは，侵食により汀線が後退 して急勾配となった。測線Cではほぼ-9mまで侵食され たがそれより沖合は緩勾配の海底面となっている。一方 測線 Dでは- $12 \mathrm{~m}$ 付近まで侵食されているようであるが, 測量誤差も含まれるので限界水深を正確に定めることは 難しい。しかし主要な地形変化はほぼ-9mで収束してい る. 以上より，大洗港の南側海岸では波による地形変化 の限界水深はほぼ-9mにあると言える。

測線 $\mathrm{B}, \mathrm{D}$ に対応する $d_{50}$ の水深分布変化を図-11,12 に 示す．堆積域の測線 $\mathrm{B}$ の汀線付近での $d_{50}$ は $0.2 \sim 0.3 \mathrm{~mm}$ 程度で, 水深が深くなるに従い $0.1 \mathrm{~mm}$ 程度に収束してい る。一方，侵食域の測線 Dの汀線付近では $d_{50}$ は時間経過

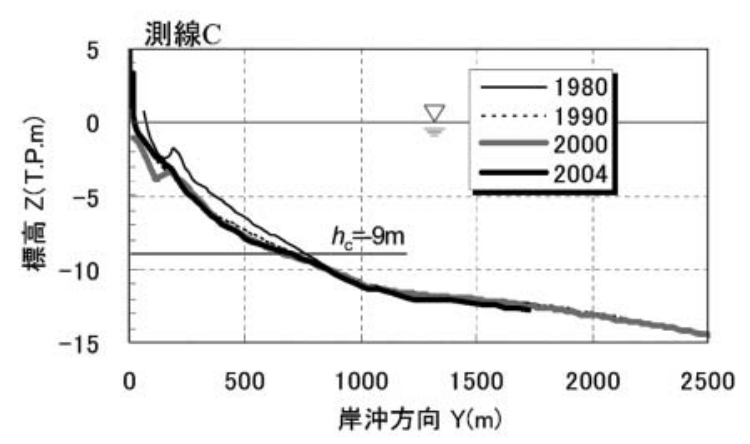

図-9 縦断形変化（測線 C）

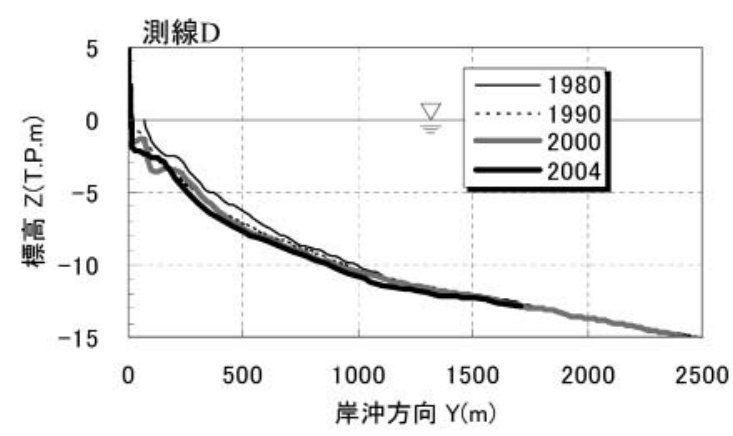

図-10 縦断形変化（測線D）

とともに粗粒化し， $0.25 \mathrm{~mm}$ から $20 \mathrm{~mm}$ と約 10 倍も増大し たことが分かる。これに対し沖合では，測線 $\mathrm{B}$ と同様の $0.1 \mathrm{~mm}$ 程度の粒径のままである。これらのデータより， 大洗港へと向かう沿岸漂砂により測線 Dでは細粒分が選 択的に流出して粗粒化し, 測線 Bでは細砂が集中的に堆 積したことが明らかである。

\section{5. 考察}

大洗港の南防波堤と沖防波堤間の，沖防波堤による波 の遮蔽域では沖防波堤に向かって舌状砂州を形成しつつ 砂が堆積している．この砂は大洗港の北 $3 \mathrm{~km}$ に位置する 那珂川からの流出土砂が堆積したと考えられ，その堆積 量は 25 年間で $1.5 \times 10^{6}$ 万 $\mathrm{m}^{3}$ であり, 堆積割合は $6.0 \times 10^{4}$ $\mathrm{m}^{3} / \mathrm{yr}$ となる．図-2 と図-5の比較によれば，海面下にゆる く砂が堆積した区域の水深はほぼ-4mから-10m の範囲に

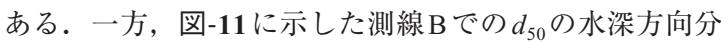
布によれば，この水深帯に堆積した砂の $d_{50}$ はほほ $0.12 \mathrm{~mm}$ の細砂である。よって両者より，南防波堤と沖 防波堤間に堆積した土砂の $d_{50}$ はほぼ $0.12 \mathrm{~mm}$ 程度の細砂 であり，これは鹿島灘の沖合の海底面を広く覆う粒径成 分と同じである．現況でこの砂の堆積域は航路へと急角 度をなして広がりつつあるから，やがて航路埋没を引き 起こす要因となりえる.ささらに本来この砂は那珂川から 


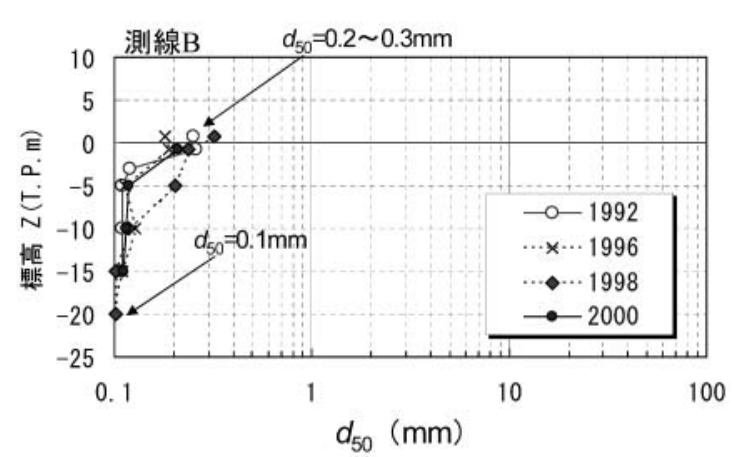

図-11 $d_{50}$ の水深分布（測線 $\mathrm{B} ）$

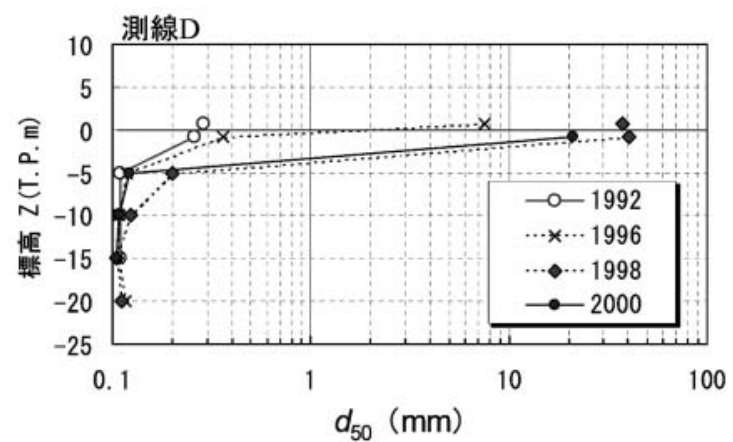

図-12 $d_{50}$ の水深分布（測線 D)

鹿島灘海岸へと供給された土砂であることを考慮すれ ば，この砂を浚渫して南側海岸の養浜材料として用いる ことが合理的である.
一方，大洗港の南側海岸では，南部から細砂が選択的 に削り取られ, 選択的に流出した細砂が波の遮蔽域に集 中的に堆積している. 結果として細砂が流出した南側海 岸では粗粒化が起こり, 海底勾配が急になる現象が起き たと推定できる. 従って大洗港への過剩な土砂堆積を防 止するために, 大洗港の南側に位置する 40 号へッドラン ドの南側に堆積した砂を南部海岸へ運ぶサンドリサイク ルを行うことが有効と考えられる. その際, 上記南防波 堤と沖防波堤からの採取土砂を南部海岸に運んで養浜を 行う場合, それが大洗港への堆砂の助長要因とならない かどうかの検討や，40号へッドランドの南側直近からの サンドリサイクルの効果検討を行うことが今後の課題で ある。

\section{参 考 文 献}

宇多高明（1997）：「日本の海岸侵食」, 山海堂, p.442.

宇多高明 - 勝山 均 - 松浦健郎 - 熊田貴之 - 長山英樹 - 大木 康弘（2007）利根川からの土砂流入のある波崎漁港周辺 の海浜変形の実態と予測, 海岸工学論文集, 第 54 巻, pp.586-590.

宇多高明 - 住谷廸夫 - 長山英樹 - 大木康弘 - 熊田貴之 (2007)： 漂砂源の涸渇と護岸の前出しによって脆弱化した海浜の 異常波浪による急激な侵食, 海洋開発論文集, 第 23 巻, pp.1201-1206.

木村 泉・佐田明義·宇多高明 - 高橋 功 - 熊田貴之 · 大木康弘 （2006）：地形・粒径変化予測モデルによるヘッドランド の漂砂制御効果の定量評価, 海岸工学論文集, 第 53 巻, pp.676-680.

三村信男 - 加藤 始 - 角田義紀 - 宮本英明 - 伊佐治進 (1991）： 大洗における港湾構造物の建設に対する海岸地形の応答, 海 岸工学論文集, 第38巻, pp.401-405. 